\title{
USE OF BUILDING STONES IN MUNICIPALITY OF ARANDJELOVAC
}

\author{
Velimir Jovanovic ${ }^{* 1}$ \\ "University of Belgrade - Faculty of Geography, Belgrade
}

\begin{abstract}
Geological building materials are among the most important natural resources. Like other natural resources, their representation is due to the corresponding natural conditions, that is, in this case, the geological structure and the tectonic structure of the terrain. Territory of the Municipality of Arandjelovac is one of the specific areas where there is long tradition of exploitation and processing of building stones , due to presence of quality raw materials.
\end{abstract}

Key words: Geological building materials, building stones, Municipality of Arandjelovac.

\section{Introduction}

Natural resources in certain area, naturally directly depend on specific natural conditions (geographic location, climate conditions, relief, hydrographic network, geological structure). Again, development of certain, sometimes dominant, economic activities is often a consequence of available natural resources. Thus, for example, on the basis of the production of certain crops, characteristic regions are distinguished, in which the corresponding natural conditions are reflected on the agricultural land as a resource. There is a similar situation with use of alternative energy sources, wood production and hunt, attractive touristic locations etc.

${ }^{1}$ Corresponding author: V. Jovanović, University of Belgrade - Faculty of Geography, Studentski trg 3/III, 11,000 Belgrade, Serbia; e-mail: jocavj@gmail.com 
Concerning geological resources, dominant factors are geological structure and tectonic relations. The vicious geological past of our regions has contributed to the wide diversity of lithological units, and for different parts of Serbia, there are significant occurrences and deposits of different raw materials. For example, magmatic processes have contributed to creation of large number of occurrence and deposits of metallic and non-metallic mineral raw materials (such as copper, possibly gold, within the Timok andesitic complex, lead and zinc or antimony in Western Serbia and Podrinje...). In lakeside neogene basins, as the remains of the Pannonian Sea, large deposits of lignite with an inevitable place in the energy balance of the country appear, as well as significant reserves of some non-metallic raw materials (such as porcelain, ceramic or refractory clays or, on the world market are highly sought after, boron and lithium or zeolite minerals). Special type of geological resources are deposits of geological building materials, mostly building stones (technical - for road construction, water facilities, building of stone constructions, concrete constructions... and architectural - for cladding, paving...) and stones for production of construction materials (Jovanović et al. 2017).

These raw materials are especially interesting from the scope of local environment. On one side, participation of local self-governance is important for their researches and exploitation, and also investments are smaller comparing to metallic, non-metallic or energetic raw materials. Part of the income from the so-called "mining royalties", like in other geological resources, also returns to the local community.

\section{Building stones in the territorry of the Municipality of Arandjelovac}

In some parts of Serbia (predisposed with favorable geological characteristics) the production of building stone appears as a significant (basic or supplementary) activity. Some of the most intrusive examples are some rural settlements on the slopes of Maljen (Jovanović, Živanović, 2007), where the low cost of exploitation is used in small mines on private estates, with relatively high quality and requested types of stone. There are also some areas in which there is a long tradition in dealing with this activity, such as a large part of the territory of the municipality of Arandjelovac. Therefore, when we want to emphasize the degree of dependence of the economy of an area on specific natural conditions, Arandjelovac is imposed as one of the most prominent examples. The simplest representation of the geological structure of the largest part of the terrain of the Arandjelovac municipality would be 
based on the existence of Palaeozoic structures, with dominant marbles and shards, in the southern parts of the terrain, while the neogenic lake sediments prevail in the north. The most remarkable yet are the breakthroughs of tertiary granitoids that build hills and low mountains in the east-west direction. Bukulja dominates, and Šutica, Orlovica and Vagan continue on it.

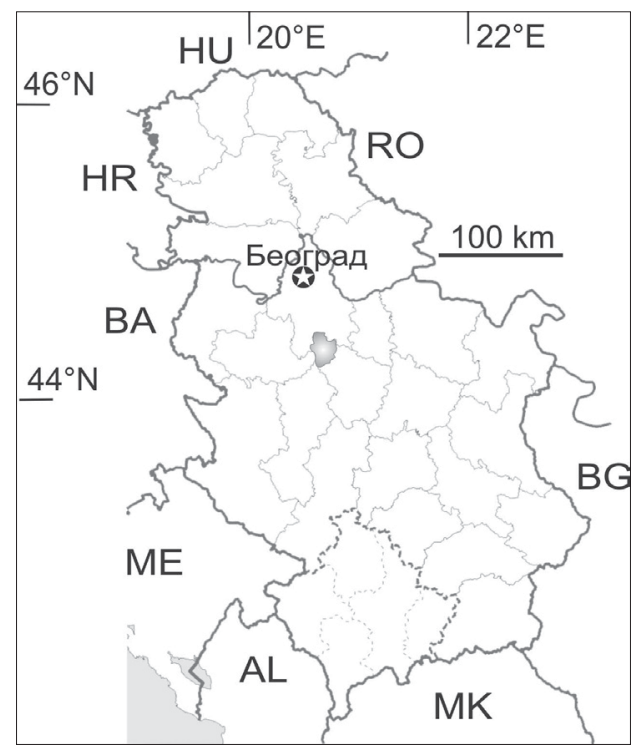

Figure 1 - Position of the municipality of Arandjelovac

Spacious masses of marbles were formed during the Paleozoic. These are white, rarely pink, fine-grained calcite marbles of outstanding qualities. Their aesthetic characteristics, susceptibility to processing and the possibility of obtaining quality blocks are significant. As such, they were used as architectural and sculptural stone. What is particularly significant is a high percentage of $\mathrm{CaCO} 3$, which in recent times qualifies it as a raw material for many industrial branches. Grind marbles, in fragments of often micronized dimensions, are used in agriculture, chemical, cosmetic and pharmaceutical industries, paper industry, construction, and so on.

Granite intrusions date between 14 and 20 million years old and break through older walls. These are light-colored two-strip granites, relatively compact, with the possibility of extracting quality blocks. The granites of Bukulja and Šutica are distinguished by their good physical and mechanical 
characteristics, as well as the durability and permanence of colors (this can be disturbed by the harsh flecking resulting from the easy decomposition of biotite from the rock, but can be prevented by polishing). They are in places sprinkled with aplite and pegmatite wires, which negatively affects their quality. The intrusion of granite pluton was accompanied by active contactmethodomatic processes and grasenization, so also the activities of tin and tungsten as well as uranium minerals (pehblende) appear here. Also, in the marginal zones of the granite masses, high quality kaolin clays appear. Along the edge of the granitoid massif, from the village of Banja to the Partizan and Rudovci in the west, numerous sources of mineral water appear.

In the neogene basins, masses of kaolinic and refractory high quality clay were formed, exceptional raw materials for the porcelain industry and refractory materials.

Arandjelovac was formed by the merging of the settlements of Vrbica and Bukovik by order of Prince Milos in 1837, and at the time of his second reign (1859), when he ordered building the church dedicated to Archangel Michael, the town got its present name. The nineteenth century is the beginning of the development of this place. For Miloš's interest, the beneficial effect of mineral water was crucial, and the beginning of their capture was also linked to his stay. In the second half of the nineteenth century, a more organized excavation of marble on Venčac started. However, more serious exploitation started at the beginning of twentieth century, when significant orders of this material came, among others, from King Peter the first Karađorđević, who at that time started building the mausoleum at Oplenac. Granites from several quarries, under the Bukulja were locally taken out and used when needed as building stone and for the construction of gravestones.

Looking at the image of the Arandjelovac economy after the World War II, we see that the most important industrial facilities are built on the basis of geological resources. Main drivers of the economy were "Shamot", industry of refractory materials, which used the deposits of refractory clay, then the "FEP" electro porcelain industry, which used high quality kaolin clay from nearby fields, Venčac, which was engaged in production, primarily architectural and ornamental, stone, based on white and pink marble and granite, "Knjaz Miloš", which is exploited and bottled mineral waters and produced refreshing beverages, as well as tourist facilities within the "Bukovička Banja" complex.

Now, when "Shamot" and "FEP" (electro porcelain) are lost in the transition period, and "Knjaz Miloš" remained with minimum of employees necessary for continuous production process, while the two of times the most 
important hotels ("Šumadija" and "Staro Zdanje") in Bukovička spa are not working, the only sustainable activity is stone exploitation and processing.

On the move from Progorevci, across the town of Darosava in the west, to the east of Banja, there are many quarries of different size and significance. Number of active quarries is very variable. From some smaller quarries, the stone is taken only occasionally, or when the need for the appropriate raw material appears.

Of the major exploitation fields there are the granite quarry Stan, Glišića Majdan, Mala Orlovica and Ploča (Babića rt). Granites from all these deposits, based on the performed laboratory analyzes, can be used for the production of aggregates and the construction of layers of road pavement structures (depending on the traffic load); for making cubes, slabs, curbs and other stone haberdashery; for all masonry and coatings in civil engineering and hydraulic engineering (Jovanović, Carević 2017). Where appropriate exploitation can be obtained, blocks of satisfactory quality can be used as architectural stone, and also for coating, paving and making tombstones.

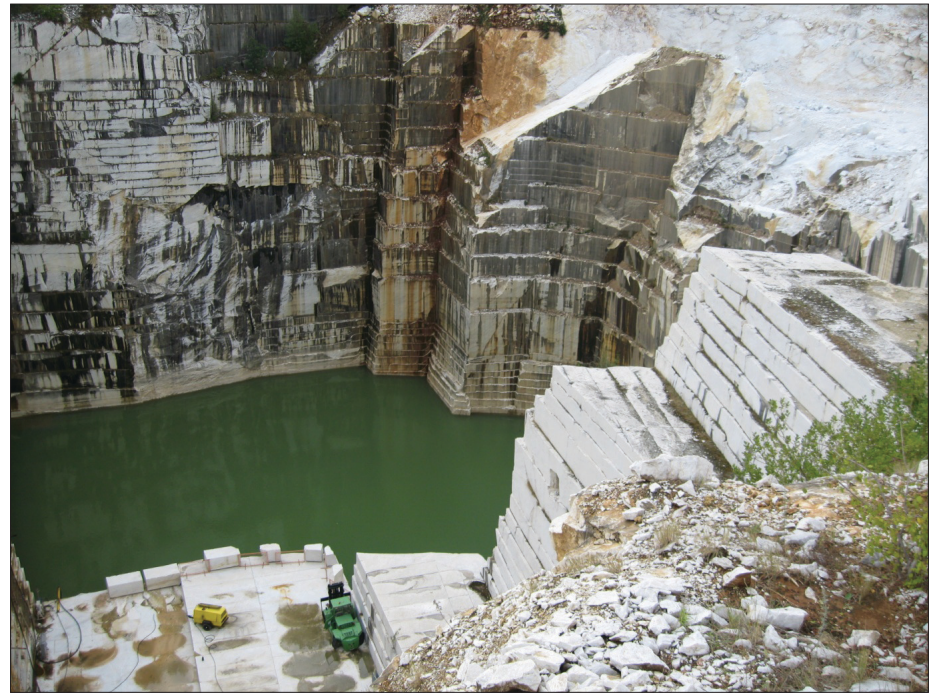

Figure 2 - Marble quarry on Venčac (Omya Venčac) 


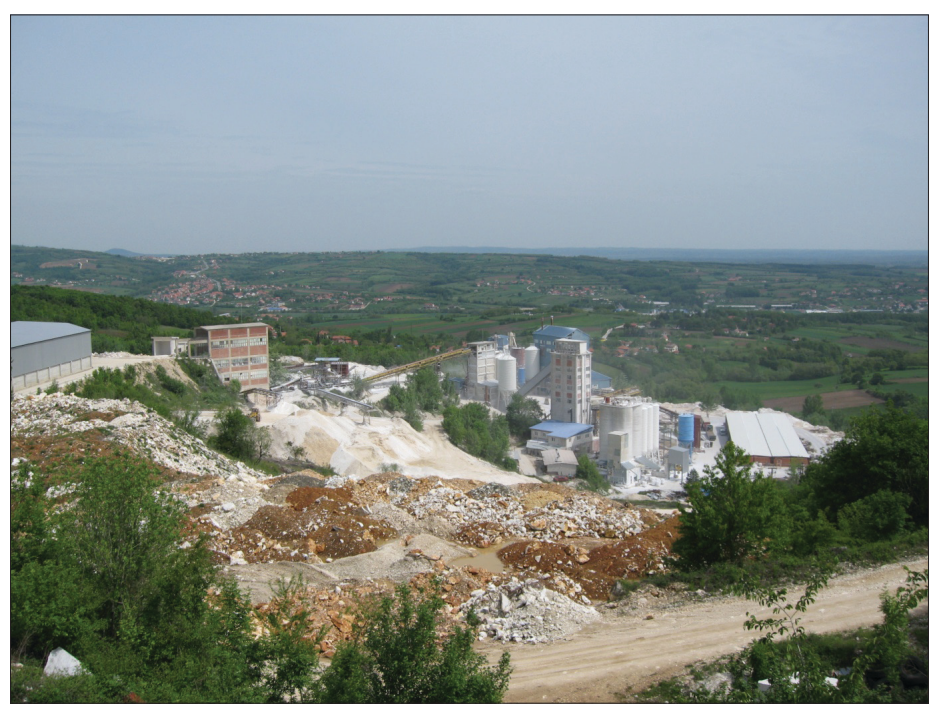

Figure 3 - The marble grinding mill (Omya Venčac)

Significant quarries in which marbles are exploited are the Vrbica Cop, Venčac, Brezovica and Krečana. Apart from marble from Krečana (due to the cracking mass, it is not possible to get blocks from which architectural stone could obtained), all others satisfy the conditions to be used as architectural stone, in the industry, for the production of aggregates and the production of mechanically or chemically stabilized lower and upper carrier layers of pavement structures (buffer, cement and bitumen stabilization) and cement concrete. As broken, the stone can be used for making stone embankments, dikes, fillings, etc. As broken or processed, it can be used for all masonry and coatings (civil engineering, hydraulic engineering) (Jovanović, Carević 2017). The exploitation of marble on Venčac is especially developed. The leading company "Omya Venčac" is engaged in the production of, in particular, ground stone material, for which there is a great demand in the market, as well as technical stone and blocks that distributes to other processors. Due to poor competitiveness (or under-profit), the processing of cutting and polishing has stopped, as well as the production of decorative items.

There are six or ten (their number varies) remaining companies or entrepreneurs dealing with exploitation in ten quarries. They are mainly engaged in the production of ground material or final products for various purposes in the construction industry (paints, binders...). 


\section{Use of Building Stones in Municipality of Arandjelovac}

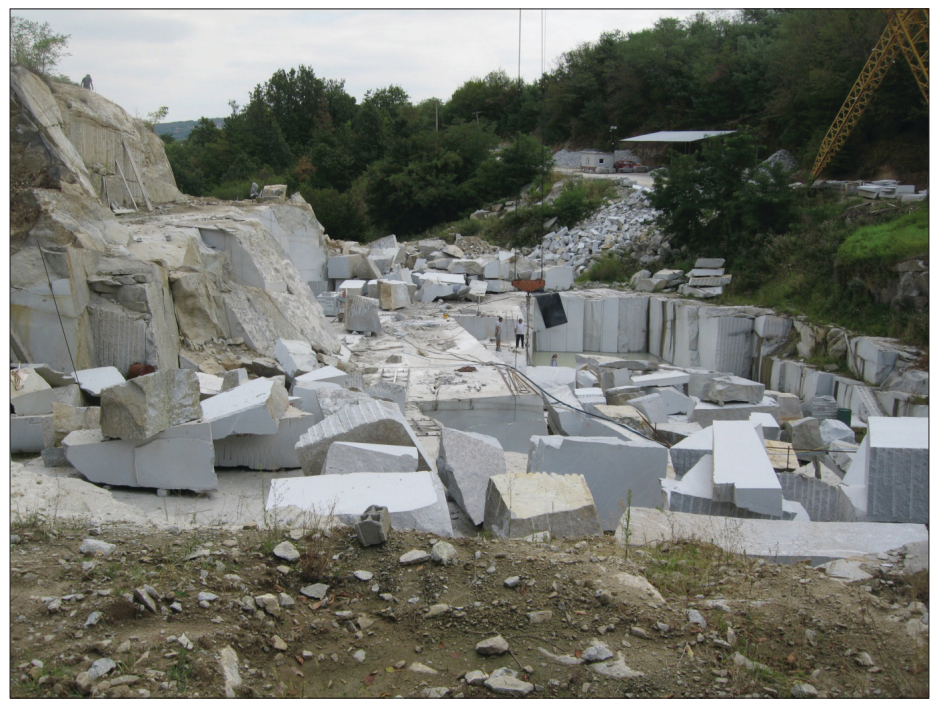

Figure 4 - Granite Quarry "Ploča“ in Bukovik

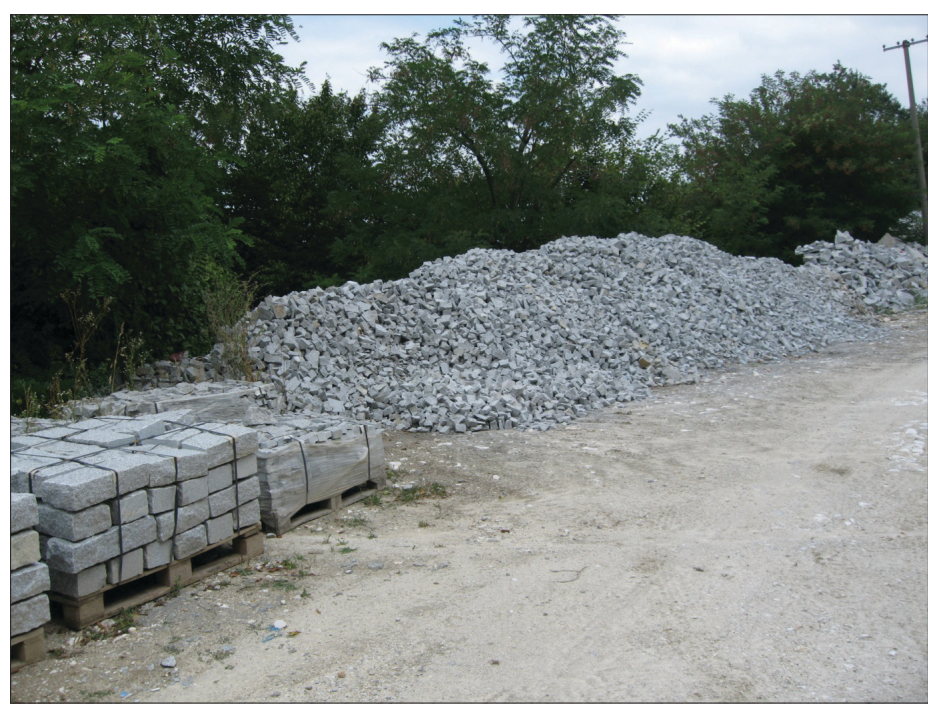

Figure 5 - Granite cubes and curbs „Ploča" 
Concerning granite, there are several active quarries on Bukulja and Šutica. According to its significance, the quarry "Ploča" ("Babica Cape"), which previously belonged to the company Venčac, is distinguished, and is now successfully privatised. After the privatisation, production has intensified and adjusted to market demand. Good blocks are made here, mainly by cutting, and less with the use of weak (deflagrant) explosives. At the very quarry "road haberdashery" is produced by carving. Quality cubes and curbs, due to the quality and durability of this stone, are increasingly demanded on the market. A part of the material is cut down on the quarry, and the rest in the processing facilities or is being distributed to other processors. Other granite quarries are much smaller and exploitation is done by smaller entrepreneurs for the needs of their processing facilities.
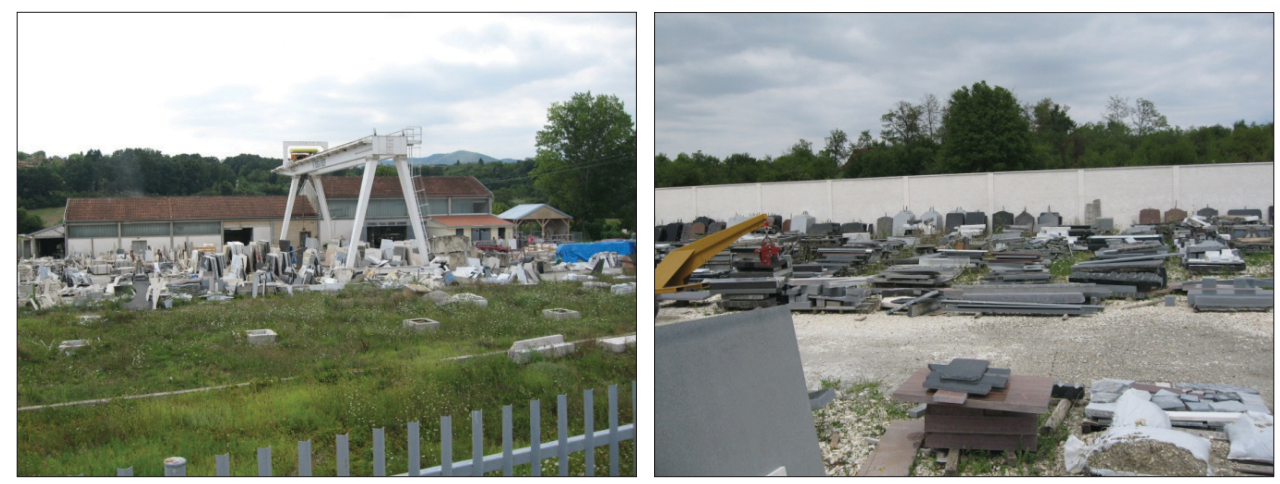

Figure 6 - Some of the major stone processing facilities

What is certainly special is a large number of those who deal with stone processing. It is undoubtedly that the beginning of this activity is related to the presence of quality raw materials in this area. Thanks to this there is a very long tradition and some families are engaged in carving and stone cutting for more than a hundred years. Some of the old masters were known among eminent, both domestic and foreign sculptors and sought to assist in the making of sculptures. A certain shift occurred in the nineties, when the first companies were established, in which the most modern stone processing equipment was installed, in order to achieve serious competitiveness on, rather problematic, market of these products. The data from the population census, which we tried to use, could show us the number of people employed in the "mining and quarrying" activity. In the 2002 census, it was a total of 771 workers, and 
according to the 2011 census, 856 workers. Data on the total number of inhabitants of the municipality of Arandjelovac who are involved in the exploitation and processing of stones could be obtained if we include those who deal only with processing, but this data does not exist in the census analyses.

\section{Conclusion}

According to the data of the competent municipal authorities, on the territory of the municipality of Arandjelovac, around thirty (number varies) deals with stone processing, either small entrepreneurs, or large enterprises. What is noteworthy is that very small quantities of materials are raw materials from local quarry, and that more and more of the stone is imported from abroad (China, Africa, South America...). Often these are raw materials or semi-finished products of unsatisfactory quality in terms of physical and mechanical characteristics or color stability, but with considerably lower prices than domestic quality stone. In any case, the production and processing of stone materials in this territory is of great importance, which can be freely said is more than just the economic. Traditionally dealing with the production and processing of stone has led to a certain recognition of Arandjelovac as one of the very centers of this activity in Serbia. It is not surprising that a significant segment of the most famous manifestation in Arandjelovac "Marble and Sounds", is t symposium "White Marble". Although there are some difficulties in the realization of this manifestation after privatization, all these years (since 1966) famous local and international sculptors leave their works in the park of Bukovička spa, contributing to the enrichment of the tourist offer.

\section{Acknowledgements}

The paper is the result of the research within the project no. 176008 funded by the Ministry of Education and Science of the Republic of Serbia.

\section{References}

Jovanović, V. \& Carević, I. (2006). Mineral raw materials as a possible factor for the development of rural areas. In the XII International Scientific Meeting "Vlasinski susreti" 2006, Belgrade-Vlasotince, 151-155. 
Jovanović, V., Živanović, Z., (2007). Struganic - village on stone. International Scientific Meeting "Власински сусрети 2007" - "Traditional and modern in work and life of rural population", Vlasotince - Vlasinsko Jezero, (614-619).

Jovanović, V., Carević, I. \& Vušković, D. (2014). The influence of local selfgovernment on land management aimed at exploring and exploiting geological resources. Fifth Scientific Conference with International Participation "Local Self-Government in Planning and Spatial Planning". Zlatibor, 175-180.

Jovanović V., Carević I. (2016): Geological building materials as a factor with potential for development of the Sumadija District. Collection of Papers Faculty of Geography at the University of Belgrade, 64, 517-542. (Print ISSN 1450-7552; Online ISSN 2334-94)

Official Gazette of RS No. 56/10. (2010). Regional spatial plan for the areas of the Šumadija, Pomoravlje, Raska and Rasina administrative districts.

Official Gazette of RS, No. 101/15. (2015). Law on Mining and Geological Exploration. 